International Journal of Public Finance
E-ISSN: $2548-0499 \quad$ DOI: $10.30927 / i j p f .319875$
Vol./Cilt: 1 I Issue/Sayı: 1 | (2016), pp. $61-74$
journal homepage: http://dergipark.gov.tr/ijpf

\title{
Elektronik Ticaretin Vergilendirilmesi Açısından Katma Değer Vergisinin Uygulama Sorunlarının Değerlendirilmesi*
}

\author{
Evaluation of Value Added Tax Application Problems in Terms of \\ Taxation of Electronic Commerce
}

\author{
Güneş ÇETIN GERGER ${ }^{1} \quad$ Adnan GERÇEK ${ }^{2}$
}

\section{ARTICLE INFO \\ Received: 10.01.2016 \\ Received in revised \\ form: 26.03.2016 \\ Accepted: 04.04.2016 \\ Available online: \\ 27.07.2016 \\ JEL classification: \\ $\mathrm{H} 2, \mathrm{~L} 81$}

\section{Keywords:}

VAT, e-Commerce, eTaxation, BEPS

\begin{abstract}
A B S T R A C T
Nowadays electronic taxation is being one of the important issues for revenue administrations. Tax administrations try to organize their tax system fairly and give attention on equity. Value added tax is most preferable taxes among the consumption taxes. Because it's application is easy and taxpayers don't show resistance to the value added tax. On electronic commerce value added taxes are using commonly. To provide equity in taxation, some taxation principles are adapted for value added taxes too. In this paper, we are trying to analyze the development of ecommerce in the world and e-taxation regulations and problems in the European Union (EU) and Organization for Economic Cooperation and Development (OECD) countries. The EU and OECD countries are making regulations in this issue. The last regulation is Base Erosion and Profit Shifting 15 point action plan in 2014. Taxation of the digital economy is the first action plan. In addition this, some regulations about taxation of digital economy are being done in Turkey in the case of Base Erosion and Profit Shifting action plan.

\section{Ö Z E T}

Günümüzde, elektronik vergilendirme gelir idareleri için önemli bir konu haline gelmiştir. Vergi idareleri, vergi sistemlerini tarafsız bir şekilde düzenlemeye çalışmakta ve adalete önem vermektedir. Katma değer vergisi, tüketim vergileri içerisinde en çok tercih edilen vergilerdendir. Çünkü uygulaması kolaydır ve mükellefler katma değer vergisine direnç göstermezler. Elektronik ticarette katma değer vergileri yaygın olarak
\end{abstract}

MAKALE BíLGisi

Alındı: 10.01 .2016 Gözden geçirilmiş alındı: 26.03 .2016 Kabul: 04.04.2016 Yayın: 27.07.2016

15-19 Mayıs 2016 tarihleri arasında düzenlenen 31. Türkiye Maliye Sempozyumu'nda sunulan metnin gözden geçirilmiş ve düzeltilmiş hâlidir.

1 Doç. Dr., Celal Bayar Üniversitesi , Uygulamalı Bilimler Yüksekokulu, gunes.cetin@cbu.edu.tr

2 Prof. Dr., Uludağ Üniversitesi, iiBF, Maliye Bölümü, agercek@uludag.edu.tr 
JEL Kodu:

H2, L81

\section{Anahtar Kelimeler:}

KDV, e-Ticaret, e-

Vergilendirme, Matrah

Aşındırma ve Kar

Aktarımı Eylem Planı kullanılmaktadır. Vergilemede adaleti sağlayabilmek için, bazı vergileme ilkeleri Katma Değer Vergisi için de benimsenmiştir. Bu çalışmada, Avrupa Birliği ve Ekonomik İşbirliği ve Kalkınma Örgütü ülkelerinde, e-vergilendirme düzenlemeleri ve sorunları, dünyadaki e-ticaretin gelişimi değerlendirilmeye çalışılmıştır. Avrupa Birliği ve Ekonomik İşbirliği ve Kalkınma Örgütü bu konuda düzenlemeler yapmaktadır. Son düzenleme, 2014 yılında Matrah Aşındırma ve Kar Aktarımı olarak 15 maddelik eylem planıdır. Dijital ekonominin vergilendirilmesi ilk eylem planıdır. Ayrıca, Matrah Aşındırma ve Kar Aktarımı eylem planında dijital ekonominin vergilendirilmesi ile ilgili bazı düzenlemeler Türkiye'de yapılmaktadır.

\section{Giriş}

Günümüzde elektronik ticaretin vergilendirilmesinde çeşitli sorunlar yaşanmaktadır. Tüketim vergisi olarak OECD ülkelerinin hemen hemen hepsinde yer alan, mal ve hizmet ticareti üzerinden alınan Katma Değer Vergisi'nin, e-ticarette de etkin bir şekilde kullanılması önemli bir konu olmuştur. Globalleşme ve ticaret yapısındaki hızlı değişim sonucu KDV ile ilgili düzenlemelere ihtiyaç duyulmuştur. Yaygın bir şekilde kullanılmasına rağmen KDV'nin tarh ve tahsil aşamaları için küresel ölçekte düzenlemeler ile fikir ve uygulama birliği tam olarak gerçekleştirilememiştir. 1998 yılında Ottawa Konferansı'nda gündeme gelen bu konu, nihayetinde OECD'nin 2013 yılında oluşturduğu, Matrah Aşındırma ve Kar Aktarımı (BEPS) Eylem Planı'nın onbeş maddelik birincisi olan dijital ekonominin vergilendirilmesi başlığı altında incelenmiştir (OECD, 2013). 2014 yılında Tüketim Vergileri Trendi ve 2015 yılında Dijital Ekonomide Vergilendirme Tartışmaları raporlarında eylem planları sonuçları yayımlanmıştır (OECD, 2014; OECD, 2015).

Bu çalışmada elektronik ticarette tüketim vergisi olarak KDV'nin global ölçekte uygulanması ile ilgili genel sorunlar ve Türk Vergi Mevzuatı'nda yer alan düzenlemeler incelenmeye çalışılmıştır. Katma Değer Vergisi Kanunu ve uluslararası vergi anlaşmaları açısından elektronik ticarete konu işlemlerin değerlendirilmesi yapılacaktır.

\section{OECD VE AB'de KDV'nin Gelişimi}

Katma Değer Vergisi (KDV), genel olarak tüm mal ve hizmetleri vergi konusuna alan, üretimden nihai tüketime kadar tüm iktisadi aşamaları kapsayan, çok aşamalı, iktisadi aşamaların her birinde yaratılan değeri kendisine matrah kabul eden bir vergi olarak tanımlanır (Şenyüz, Yüce, Gerçek: 2015, 241).

1998 yılında Ottawa konferansında elektronik ticarette Katma Değer Vergisi (KDV) konusu ilk kez düzenlenmiştir. AB'de ise ortak KDV sistemi 2002 yılında düzenlenmiştir (Ferhatoğlu, 2006: 2). Birçok ülkede son yirmi yılda ortak vergi politikaları, uluslararası kuruluşların etkisi olmaksızın uygulanmaktadır. Temel bir vergi geliri kaynağı olan KDV, uluslararası bir programın sonucu olarak değil, ülkeler tarafından tek taraflı olarak yeniden yapılandırılmıştır (UN, 2005: 8). KDV üretim aşamasından nihai tüketim aşamasına kadar alınan geniş tabanlı bir vergidir. Hane halkından alınan son tüketim vergisidir. Üretimin ve dağıtımın her aşamasından alındığı için tedarik zincirindeki her işletme verginin tahsilatında ve kontrolünde yer alır (OECD, 
2015: 11). Genel olarak OECD ülkelerinde KDV, nihai tüketici dışında ekonomik işlemin her aşamasında mahsup edilir. Dünya'da 160 ülkede, OECD ülkelerinin ABD hariç 33'ünde uygulanmaktadır (OECD, 2014: 14). OECD ülkelerinde oransal olarak tüketim vergileri \%31'lik bir pay oluşturarak vergi gelirleri arasında en önemlisi olmuştur.

Şekil 1: Toplam Vergiler İçerisinde Vergi Türlerine Göre Ortalama Sınıflandırma



Kaynak: OECD (2014), Consumption Tax Trends 2014, OECD Publishing. http://dx.doi.org/10.1787/ctt-2014-en

Dünya'da KDV uygulayan ülkelerin sayısı 1960'dan günümüze oldukça büyük miktarda artış göstermiştir. Şekil 2'de gözlenebilir.

\section{Şekil 2: KDV Uygulayan Ülkelerin 1960-2014 Yılları Arası Değişimi}

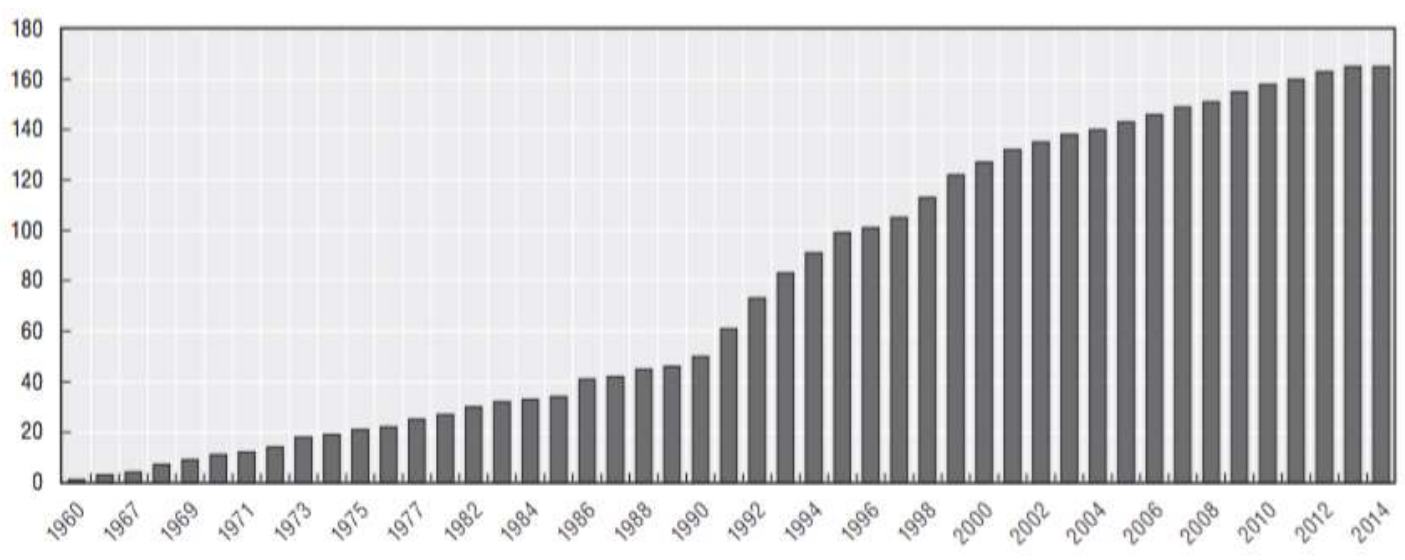

Kaynak: OECD (2014), Consumption Tax Trends 2014, OECD Publishing. http://dx.doi.org/10.1787/ctt-2014-en, s.18.

OECD ülkelerinde yaygın olarak kullanılan KDV günümüzde vergi gelirleri içerisinde önemli bir paya sahiptir. KDV'nin 1965-2012 yılları arasın ülkelerin toplam vergi gelirleri içerisindeki KDV oranı Tablo 1'den izlenebilir. Özellikle 1980'lerden bu 
yana, ülkelerin elde ettiği vergi gelirleri içinde KDV geliri oranı, önemli bir artış trendiyle beraber yükselen bir paya sahip olmuştur. Dolaylı bir vergi olan KDV'nin uygulama kolaylığı, vergi tahsilatında etkinlik bu verginin yaygınlaşmasını beraberinde getirmiştir. Vergi geliri içerisinde KDV gelirinin toplam vergi gelirlerine oranı en yüksek paya sahip olan ülkeler Şili (\% 37.7), Yeni Zelanda (\%30), Portekiz'dir (\%26.4). En düşük paya sahip ülkeler ise Japonya (\%9,2), Avusturalya (\% 12,1), İsviçre'dir (\% 13.1). Amerika Birleşik Devletleri OECD ülkeleri içinde KDV'yi uygulamayan tek ülke olmasına rağmen, KDV yerine yine bir tüketim vergisi olan Satış Vergilerini (GST) kullanmaktadır.

Tablo 1: KDV'nin Toplam Vergi Gelirleri İçerisindeki Oranı

\begin{tabular}{|c|c|c|c|c|c|c|c|c|c|c|c|}
\hline & 1965 & 1975 & 1985 & 1995 & 2000 & 2005 & 2009 & 2010 & 2011 & 2012 & $\begin{array}{c}\text { Difference } \\
2000-12\end{array}$ \\
\hline Australia & 0.0 & 0.0 & 0.0 & 0.0 & 11.1 & 13.1 & 13.9 & 13.4 & 12.5 & 12.1 & 1.0 \\
\hline Austria & 0.0 & 19.8 & 21.0 & 18.6 & 18.8 & 18.8 & 19.0 & 18.9 & 18.6 & 18.6 & .0 .2 \\
\hline Belgium & 0.0 & 16.2 & 15.7 & 15.2 & 16.1 & 15.8 & 16.0 & 16.2 & 15.9 & 15.7 & .0 .4 \\
\hline Canada & 0.0 & 0.0 & 0.0 & 8.4 & 9.2 & 9.9 & 8.4 & 12.2 & 13.5 & 13.7 & 4.5 \\
\hline Chile & .* & . & . & 40.6 & 41.8 & 37.8 & 42.5 & 38.7 & 37.0 & 37.7 & -4.1 \\
\hline Czech Republic & &. & .. & 16.6 & 18.3 & 19.1 & 20.4 & 20.5 & 20.6 & 20.9 & 2.6 \\
\hline Denmark & . & 17.3 & 20.2 & 19.3 & 19.3 & 19.7 & 21.2 & 20.6 & 20.7 & 20.6 & 1.3 \\
\hline Estonia & &. & .. & 26.5 & 27.3 & 28.3 & 24.8 & 25.7 & 26.0 & 26.6 & -0.7 \\
\hline Finland & 18.5 & 15.6 & 18.3 & 17.4 & 17.4 & 19.9 & 20.5 & 20.4 & 20.9 & 21.1 & 3.7 \\
\hline France & 20.1 & 23.1 & 19.7 & 17.4 & 16.7 & 16.7 & 16.2 & 16.3 & 15.9 & 15.5 & -1.2 \\
\hline Germany & 0.0 & 14.6 & 15.8 & 17.4 & 18.4 & 18.0 & 20.1 & 20.0 & 19.7 & 19.4 & 1.0 \\
\hline Greece & 0.0 & 0.0 & 0.0 & 22.0 & 20.8 & 21.5 & 21.1 & 23.2 & 22.3 & 21.2 & 0.4 \\
\hline Hungary &. &. & . & 17.8 & 22.4 & 22.6 & 21.5 & 23.0 & 23.0 & 23.7 & 1.3 \\
\hline Iceland & 0.0 & 0.0 & 0.0 & 29.9 & 28.5 & 27.3 & 23.7 & 22.7 & 22.4 & 22.8 & -5.7 \\
\hline Ireland & 0.0 & 14.7 & 20.6 & 21.1 & 23.0 & 24.8 & 22.7 & 22.8 & 21.4 & 21.7 & -1.3 \\
\hline Israel & .. & .. & .. & 23.5 & 21.3 & 22.5 & 24.6 & 24.7 & 24.6 & 24.7 & 3.4 \\
\hline Italy & 0.0 & 13.7 & 14.5 & 13.8 & 15.4 & 14.6 & 13.1 & 14.6 & 14.5 & 13.8 & -1.6 \\
\hline Japan & .. & .. & .. & 5.4 & 9.1 & 9.5 & 9.6 & 9.6 & 9.4 & 9.2 & 0.1 \\
\hline Korea & .. & 0.0 & 21.1 & 17.8 & 17.0 & 17.4 & 17.3 & 17.6 & 17.1 & 17.2 & 0.2 \\
\hline Luxembourg & 0.0 & 12.1 & 12.8 & 14.0 & 14.3 & 16.4 & 16.8 & 16.8 & 17.4 & 18.2 & 3.9 \\
\hline Mexico & .. & 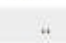 & 15.9 & 16.9 & 18.7 & 19.1 & 19.7 & 20.5 & 19.0 & 19.0 & 0.3 \\
\hline Netheriands & 0.0 & 14.4 & 16.2 & 15.6 & 17.5 & 19.6 & 18.3 & 18.7 & 18.0 & 17.9 & 0.4 \\
\hline New Zealand & 0.0 & 0.0 & 0.0 & 22.8 & 24.9 & 23.8 & 27.6 & 30.7 & 30.9 & 30.0 & 5.1 \\
\hline Norway & 0.0 & 20.5 & 18.2 & 21.2 & 19.7 & 18.1 & 18.6 & 18.5 & 18.0 & 18.2 & -1.5 \\
\hline Poland & .. & 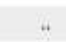 & - & 17.0 & 21.2 & 22.9 & 22.9 & 24.0 & 24.5 & 22.1 & 0.9 \\
\hline Portugal & 0.0 & 0.0 & 0.0 & 23.6 & 24.8 & 27.1 & 23.1 & 25.0 & 25.3 & 26.4 & 1.6 \\
\hline Slovak Republic &. &. & . & 20.8 & 20.4 & 25.0 & 23.3 & 22.4 & 23.7 & 21.3 & 0.9 \\
\hline Slovenia & .. &.. & .. & 0.0 & 23.3 & 22.2 & 21.9 & 22.0 & 22.4 & 22.0 & -1.3 \\
\hline Spain & 0.0 & 0.0 & 0.0 & 15.9 & 17.6 & 17.8 & 12.6 & 16.8 & 16.5 & 16.6 & -1.0 \\
\hline Sweden & 0.0 & 12.0 & 14.0 & 19.4 & 16.9 & 18.3 & 20.7 & 21.3 & 21.4 & 21.1 & 4.2 \\
\hline Switzerland & 0.0 & 0.0 & 0.0 & 8.6 & 13.1 & 13.5 & 12.3 & 12.8 & 12.8 & 13.0 & -0.1 \\
\hline Turkey & .. & .. & 22.3 & 24.3 & 24.2 & 21.8 & 20.0 & 21.7 & 21.8 & 20.8 & -3.4 \\
\hline United Kingdom & 0.0 & 8.9 & 15.9 & 19.0 & 18.1 & 18.6 & 16.6 & 18.8 & 20.5 & 20.8 & 2.7 \\
\hline United States & 0.0 & 0.0 & 0.0 & 0.0 & 0.0 & 0.0 & 0.0 & 0.0 & 0.0 & 0.0 & 0.0 \\
\hline \multicolumn{12}{|c|}{ Unweighted average } \\
\hline OECD-average & 1.8 & 8.8 & 11.3 & 17.3 & 19 & 19.5 & 19.2 & 19.7 & 19.7 & 19.5 & 0.5 \\
\hline
\end{tabular}

Kaynak: OECD (2014), Consumption Tax Trends 2014, OECD Publishing. http://dx.doi.org/10.1787/ctt2014-en, s.40.

KDV'nin gelişimine baktığımızda, birinci dönem olarak nitelendirilen 1975-2000 yılları arasında KDV uygulayan ülkelerde standart KDV oranlarının yükseldiği, ikinci dönem olan 2000-2009 yılları arasında ise bu oranın genel olarak sabit kaldığı, hatta 
ortalama standart KDV oranının \%18'den \%17,6'ya küçük bir oranda düştüğü görülmektedir. Üçüncü dönem olarak nitelendirilen 2009-2014 yılları arası ise birçok ülkede standart KDV oranında yeni bir artış dalgası yaşanmıştır (OECD, 2014; 44) .

Özellikle Avrupa Birliği ülkelerinde (Çek Cumhuriyeti, Estonya, Finlandiya, Fransa, Yunanistan, Macaristan, İrlanda, İtalya, Hollanda, Polonya, Portekiz, Slovak Cumhuriyeti, Slovenya, İspanya, İngiltere) standart KDV oranlarında artış vardır ve birlik üyesi olmayan bazı ülkelerde de artış olmuştur (İzlanda, İsrail, Japonya Meksika, Yeni Zelanda, İsviçre). 2009'da \%17,6 olan ortalama standart KDV oranı \%19,1'e yükselmiştir. Aşağıdaki Şekil 3'de ülkelerin KDV oranları izlenebilir (OECD, 2014: 40).

Şekil 3: Ülkelerin Standart KDV Oranları (2014 Yılı)

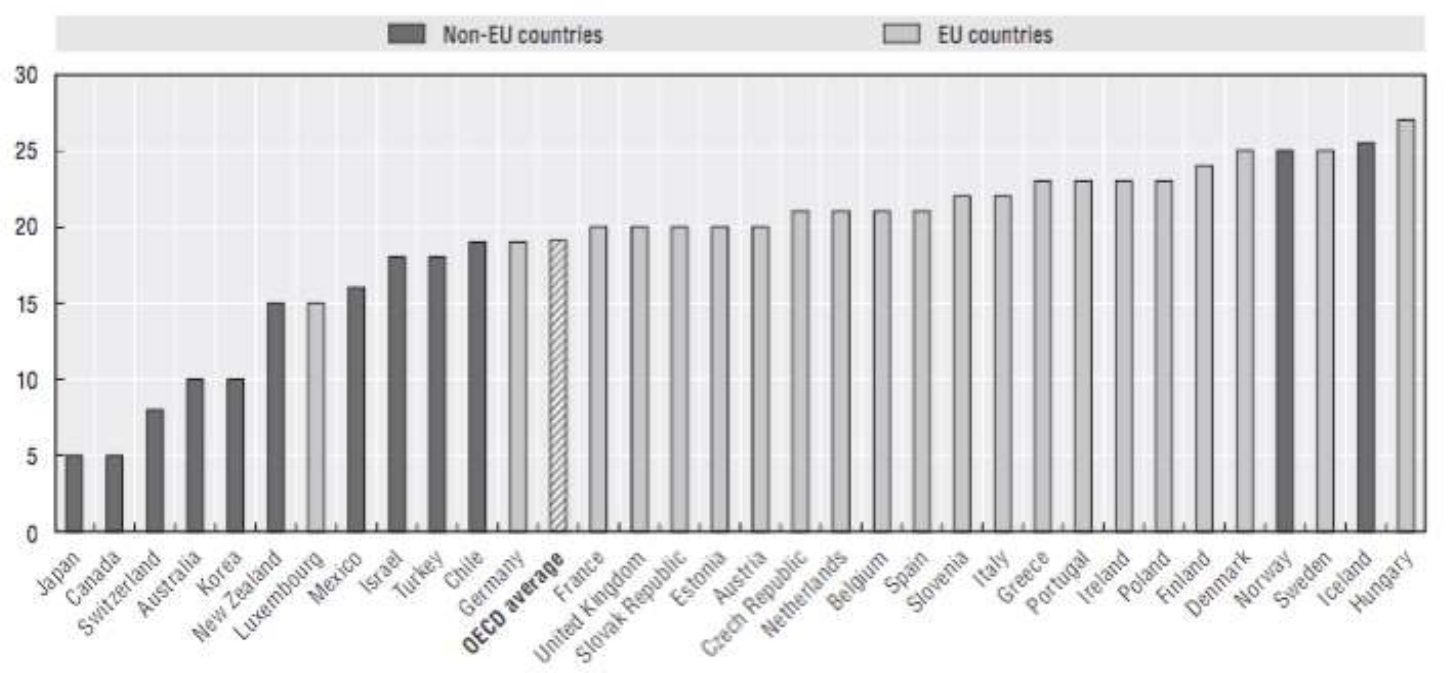

Kaynak: OECD (2014), Consumption Tax Trends 2014, OECD Publishing. s.45.

\section{Elektronik ticarette KDV sorunu ile ilgili $O E C D$ ve $A B$ düzenlemeleri}

\subsection{Elektronik Ticarette KDV Sorunu}

Günümüzde elektronik ticaret, dünya ticaret hacminin önemli bir kısmını oluşturmaktadır. Elektronik ticaretin yaygınlaşması ile birlikte, tüketim vergilerinden en çok kullanılan KDV veya Satış Vergileri (VAT/GST) konusunda düzenlemeler yapılması gündeme gelmiştir. Görüldüğü gibi KDV ülkelerin önemli bir vergi geliri kaynağıdır. Bu yüzden bu alanda yapılacak düzenlemeler KDV kaybının önlenmesi için gereklidir.

Elektronik ticarette KDV ile ilgili sorunlar yerelsellik ilkesinin uygulanmasına dayalı teslim veya ifa yerinin belirlenmesinde ortaya çıkmıştır. Bu sorun malın niteliğine göre de değişebilmektedir. Sınırdan geçen maddi eşya geleneksel yöntemlerle vergilendirilirken, hem siparişin hem de teslimin çevrimiçi bir şekilde tamamlandığı hallerde bunların mal mı, yoksa hizmet mi olarak değerlendirileceği konusunda sorun yaşanmaktadır (Yaltı, 2003: 215). Fiziki malların teslimiyle sonuçlanan elektronik ticarette herhangi bir sorun yaşanmamaktadır. Fiziki mallar teslim edildiği yerde tarh ve tahakkuk ettirilir. Hem gümrük vergileri hem de KDV gümrükten geçtiğinde tahsil edilir. 
Birçok ülkede bu şekilde bir uygulama vardır. Elektronik ticaretin bilgisayar verileriyle transferinin mümkün olduğu; müzik, video, e-kitap gibi dijital ürünlerin sınır ötesi satışında malların tesliminde KDV açısından sorun yaşanmaktadır. Çünkü malların tesliminde izlenebilir bir belirtisi yoktur.

Dolaysız elektronik ticaret hem siparişin hem de teslimin çevrimiçi bir biçimde tamamlandığı zamanlarda, yani kitap, müzik CD’si, dergi gibi malların sanal mallara dönüştüğü zamanlarda bu malların nitelendirilmesinde hizmet mi yoksa mal olarak değerlendirilmesi gerektiği sorunu ortaya çıkacaktır. İşlemin mal ve hizmet olmasına göre ifa yeri kuralı farklılaşır, uygulanacak vergi oranları da değişebilir (Yaltı, 2003: 215).

Ayrıca diğer bir konu da teknoloji transferlerinde KDV sorunudur. Teknoloji transferleri de üç grupta değerlendirilebilir; Fiziki mallar, sanal mallar ve bilgi ve beceriler. Bunları kesin çizgilerle sınıflandırmak zordur. Çünkü bir software (CD içinde) fiziki olarak da teslim edilebilir, elektronik olarak da teslim edilebilir. Bazı ülkelerde mülkiyet öğesi sayılabilir, bazılarında sayılmayabilir. Teknoloji transferi bir ülkeden diğerine çeşitli şekillerde yapılabilir. Bunlar; hizmetin kiralanması, lisansına veya provizyonuna sahip olma gibidir. Mülkiyet tipi, transfer şekli, ödeme şekli teknoloji transferindeki vergi anlaşmasını etkileyebilir (UN, 2005: 7).

\subsection{OECD’nin ve $A B$ 'nin Yaptığı Düzenlemeler}

2001 yılında yapılan düzenlemede; e-ticarete konu olan sanal malın, işletmeden-işletmeye olan e-ticarette, alıcı olan işletmenin varlığının tüketimin yapıldığı yerde bulunması koşulu ve işletmeden-müşteriye yapılan e-ticarette ise alıcının ikametgahının bulunduğu yer koşulu getirilmiştir. 2003 ve 2006 yıllarında sanal mal ve hizmetler için e-ticaret $O E C D^{\prime}$ nin yeni rehberlerinde düzenlenmiştir (OECD, 2014: 28). Nihai olarak, 2014 yılında OECD uluslararası KDV tasarımı ve işlemleri ile ilgili standartları şöyle belirlemiştir;

KDV'nin Tarafsızlığı Üzerine Standartlar: KDV tüketim üzerinden alınan bir vergidir. İşletmeler üzerinden alınan bir vergi değildir, ancak işletmeler sadece bu verginin tahsildarıdır. Bu standartlar yerleşik bir işletmeyi sınır ötesi ticarette, yurt dışında tahsil edilemeyecek KDV'ye maruz kalmaktan korur (OECD, 2014: 30).

Uluslararası Ticarette Vergileme Haklarının Dağılımı Standartları: İşletmeden işletmeye (B2B) sanal mal ve hizmet satışında alıcın ülkesinde vergilendirilir. Bu ilke "varış yeri temelli" vergileme standardı olarak ulusal KDV sistemlerince de uygulanır (OECD, 2014: 28). Günümüzde yaygın olarak kullanılan işletmeden-müşteriye işlemlerinde KDV uygulaması ile ilgili olarak ortak bir hukuk birliği sağlanmaya çalışılmaktadır. 2014'te yayınlanan BEPS raporunda "Dijital Ekonominin Vergi Sorunları" başlığı altında KDV konusunda uluslararası bir çerçevenin eksikliğinden bahsedilmiştir.

KDV'de uluslararası ticaretin vergilendirilmesinde varış yeri ilkesi benimsenir. Varış yeri ilkesi uygulaması, uluslararası ticarette tarafsızlığı sağlar, bu yüzden varış yeri ilkesi konusunda yaygın bir hukuk birliği vardır (OECD, 2015: 12). 
1998'de Ottawa Konferansı'nda vergi politikası açısından genel olarak kabul edilen vergileme prensipleri, KDV için de kabul edilebilir. Bunlar; tarafsızlık, verimlilik, kesinlik ve basitlik, etkinlik ve adalet ile esnekliktir. Tarafsızlık, elektronik ticarette KDV'nin eşit ve tarafsı şekilde düzenlenmesinde en önemli prensiptir. Aynı durumda olup benzer işlemi yapan mükellefler benzer oranda vergilendirilmelidir (OECD, 2015: 15).

KDV iki kategoride incelenebilir; mallar ve hizmetler üzerinden alınan genel bir KDV, satış vergisi gibi, diğeri ise özel mal ve hizmetlerden alınan KDV'dir. Bunlar da tüketim vergisi, gümrük ve ithalat vergisi gibidir (OECD, 2014, 15).

Avrupa Komisyonu, sınır ötesi ticarette KDV uygulamasının etkilerini incelemiştir. Değerlendirmeler soncunda, Avrupa Birliği $(A B)$ müşterileri tarafından, $A B$ dışından olan mallara artan bir talep olduğunu ve harcama yapıldığını gözlemlemiştir. Dolayısıyla söz konusu sevkiyatların gerçekleşirken takip edilmesi gereken önemli bir konu olduğu vurgulanmıştır. Bu nedenle komisyon zararlı vergi rekabetine neden olan elektronik hizmet satışına dikkat çekmektedir. Çünkü yurt dışından gelen KDV'siz elektronik hizmetler ya da düşük oranlı KDV'ye tabi olan hizmetler yurt içi işletmeler için sorun oluşturmaktadır (NAO, 2006: 8).

AB ortak KDV sisteminde 1999 yılında ve 2002 yılında yapılan değişiklikler altıncı KDV direktifinin hizmet olarak kabul edilen ve elektronik ticarete konu olan dijital ürünlerin KDV'ye tabi tutulmasını özel kurallara bağlamıştır. Sınır ötesi ticarette KDV gibi dolaylı vergilemenin hizmetin tüketildiği yerde alınması gerektiğini kabul etmiştir (NAO, 2006: 8).

$A B, 1$ Ocak 2015'den itibaren dijital ürünlerin katma değer vergisinde yeni bir uygulama başlatmıştır. Avrupa Birliği Konseyi'nin uygulamaya koyduğu 1042/2013 sayılı düzenlemesi ile telekomünikasyon, yayım ve elektronik hizmetlerde, satıcının bulunduğu yere göre KDV alınması yerine vergilendirmede tüketicinin bulunduğu ülkenin esas alındığı sistemi getirmiştir. Bu düzenleme; GSM, telefon, internet sağlama, televizyon ve radyo yayımcılı̆̆ı, yazılım, bulut teknolojisi, online oyun, e-öğrenme, ekurs, e-kitap, müzik ve video yükleme, hosting, online ödeme sistemleri gibi alanlarda faaliyet gösteren işletmeler için geçerlidir. Örneğin; İngiltere'de yaşayan bir tüketici Finlandiya'da faaliyet gösteren işletmeden cep telefonuna bir uygulama indirdiğinde, Finli şirketin tüketiciye İngiltere'de geçerli KDV'yi uygulaması gerekmektedir. Ya da İspanya'da yaşayan bir tüketici Amerikan kanallarına erişim için ödeme yaptığında, Amerikalı şirketin İspanya için geçerli KDV'yi tahsil etmesi gerekir (EUC, 2014: 10-20).

Üye ülkeler arasında elektronik ortamda bilgi değişimi yapılabilmesi için KDV alanında KDV Bilgi Değişim Sistemi (VIES), Birlik dışından yapılan e-ticaret konusunda elektronik hizmetler üzerine vergileme (VOES), ÖTV ile ilgili olarak Özel Tüketim Vergisine Tabi Mallar Hareket Kontrol Sistemi (EMCS) gibi bilgi işlem sistemleri oluşturulması gerekmektedir (http://www.ab.gov.tr/index.php?p=81-, Erişim: 22.1.2016).

Elektronik hizmetler üzerine vergileme (VOES) sistemi $A B$ üyesi olamayan işletmelerin $A B$ içinde bir vergi idaresine kayıt yaptırıp KDV'yi ödeme sistemidir. Üye 
devletlerde müşterisi olan devletler kayıt yaptırabilir. Bu program altında bütün muameleler vergiye tabidir. İşletmelerdeki önemli değişiklikler, müşterilerinin nerede olduğunu belirlemek ve elektronik hizmetlerden doğru KDV'yi doğru üye ülkeden alabilmeyi gerektirmiştir. OECD yapılan ödemelerdeki fatura bilgisine bakılarak müşteri konumunu belirlemek, takip yazılımı kullanmak, kart bilgilerini kullanmak gibi birçok yöntem önerilmiştir. Müşterinin yeri ve durumu hakkındaki bilgiler için İngiltere Ulusal Denetim Ofisi (NAO) bazı ayrıntıların dikkat edilmesi gerektiğini belirtmiştir (NAO, 2006: 20). Kural olarak; Müşterinin posta adresi ürünün ve faturanın gönderileceği adres ile aynı olmalıdır. Ayrıca ödeme kredi kartı ile kabul edilmeli ve müşterinin ev adresi ve fatura adresi kıyaslanmalıdır. Diğer bir önlem de, ödeme kredi kartı ile olmalı, özel yazılım kullanılmalı ve kredi kartının bulunduğu banka ve müşterinin ülkesi karşılaştırılmalıdır. Son olarak geolocation ${ }^{3}$ (coğrafik yer) veya özel yazılım kullanılması yoluyla müşterinin yeri tespit edilip KDV uygulaması, hizmeti kullandığı ülkenin geçerli oranlarına göre yapılır.

Bütün bu uygulamaların etkin işleyebilmesi için iyi bir denetim sistemi oluşturulmalıdır. Doğru verilere ulaşmak ancak teknolojiyi kullanarak mümkün olabilir. Bunun için özel yazılımlar kullanılmalıdır. Gelir idareleri program üreticilerinden destek almalıdır. Elektronik noterler ${ }^{4}$ tarafından verilen zaman damgası gibi uygulamaların kullanılması ise denetimin güvenirliğini daha da arttıracaktır (OECD, 2001: 76).

\section{Günümüzde Elektronik Ticaretin Gelişimi ve BEPS Planında KDV'nin Durumu}

Elektronik ticaret, mal ve hizmetlerin sipariş edilip geleneksel yöntemlerle teslimi (offline ticaret) veya mal ve hizmetlerin tamamen elektronik ortamda teslimini oluşturan online e-ticaret biçiminde yapılabilir. Elektronik ticaret yaygın olarak işletmeden işletmeye (B2B), işletmeden müşteriye (B2C) veya müşteriden müşteriye (C2C) ticari işlemlerdir (OECD, 2015: 55-56).

Dünya'da 2014 yılında işletmeden işletmeye (B2B) elektronik ticaret satışları 1.4 trilyon doları aşmıştır. B2B satışların 2018'de 2.356 trilyon dolar olacağı tahmin edilmektedir (OECD, 2015: 56; Vidyasekar, Archana Devi, 2014).

Son yıllarda, Bilgi İşlem Teknolojisi (BIT) hizmetlerinin sunumunda birçok önemli değişim meydana gelmiştir. Hindistan hızla BiT hizmetlerinin lider ihracatçısı haline gelmiştir. Hindistan'ı, İrlanda, ABD, Almanya ve İngiltere izlemektedir. Çin de önemli ihracatçılarından biri haline gelmiştir. Bu altı ülkenin yaptığı BiT hizmetlerinin ihracat toplamı toplam ihracatın yaklaşık \% 60'ını oluşturmaktadır.

\footnotetext{
3 Tarayıcının kendi içindeki komutları kullanarak kullanıcının yerini saptamasıdır.

4 Elektronik ortamdaki bilgi ve dosyalar için noterlik hizmeti veren kuruluşlardır. Müşterilerine belirli bir veri ya da dosyanın belirli bir zamanda, tam olarak var olduğunu gösterirler. Yasalarla uyumlu genel güvenlik oluşturmak, fikir haklarını korumak veya e-ticaret işletmelerinde bir işlemin reddi durumunda tarafları korumak için kullanılabilirler (http://www.eticaret.com/e-ticaret-sozlugu/sayisalnoter-nedir/).
} 
Şekil 4: Ülkelerin Biт ìhracatı (2013)

(Percentage shares of total world services exports in USD billions )

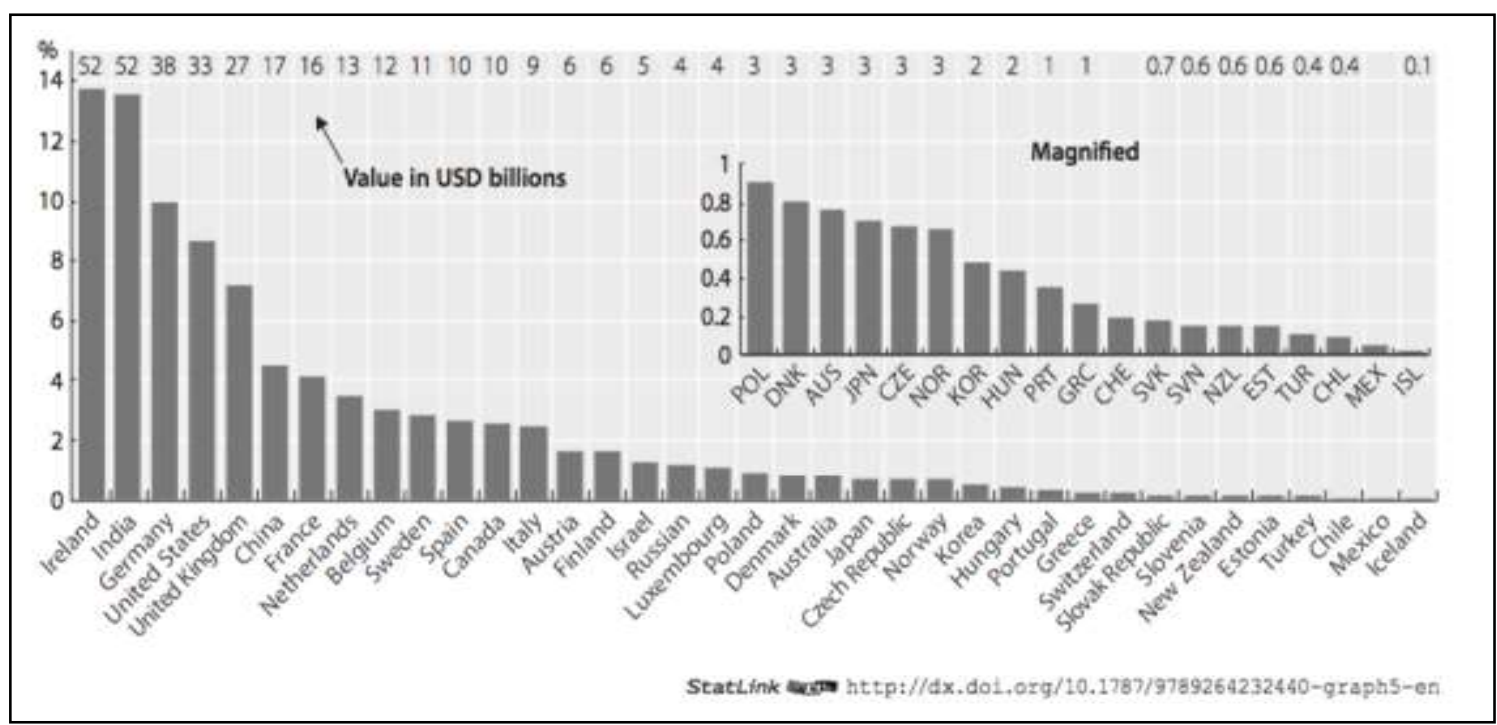

Kaynak: (2015), Addressing the Tax Challenges of the Digital Economy, Action 1 - 2015 Final Report, OECD/G20 Base Erosion and Profit Shifting Project, OECD Publishing, Paris. http://dx.doi.org/10.1787/9789264241046-en s.66.

2013 itibariyle, yaklaşık 7,1 milyar olan dünya nüfusunun 2,8 milyarı, yani $\% 39$ 'u, internet kullanıcısı haline gelmiştir. Son on yılda internetin gelişimi ve yayılımı hızlı bir şekilde ilerlemiş ve internet kullanıc sayısı yaklaşık 6 kat artmıştır (TUSiAD, 2014: http://e-ticaretzirvesi.org/turkiye-ve-dunyada-e-ticaret/ erişim.10.1.2016)

Matrah Aşındırma ve Kar Aktarımı (BEPS) son yıllarda ülkelerin gelir idarelerinin ve uluslararası kuruluşların dikkatini çeken önemli bir konu haline gelmiştir. Farklı ülkelerde şubeleri bulunan çok uluslu şirketlerin faaliyet gösterdikleri ülkelerde neden oldukları vergi kayıpları sorunlarına neden olmuştur. Bu kayıpların önüne geçmek üzere uluslararası platformlarda yeni kurumsal çerçevelerin ve BEPS ile mücadeleye ilişkin yol haritalarının oluşturulması çabasını ortaya çıkarmıştır. Günümüzde mevcut düzenlemeler çok uluslu şirketlerin neden olduğu kayıpları önlemede yetersiz kalmıştır. Bir yandan da devletler uluslararası sermayeyi çekebilmek için rekabete girmektedirler. Her ülkenin kendine ait farklı vergi mevzuatı, vergi uygulamalarındaki boşluklar durumu daha da komplike hale getirmektedir. Bu boşluklar uluslararası şirketlerce kullanılıp, matrah aşındırma ve kar aktarımı konusunda fırsat yaratmıştır. Biryandan dijital ekonomide meydana gelen gelişmeler de, uluslararası vergi uygulamaları açısından sorunlar yaratmıştır. Bu yüzden, Dijital ekonomi BEPS'in 15 Eylem planı içerinde 1. Eylem planı olmuştur. Temmuz 2013'de, G20 ülkelerinin Maliye Bakanları BEPS konusunda işbirliğine gidilmek üzere bir çağrıda bulunmuş ve bu fırsatları azaltmak için eylem planları oluşturulmuştur (Turunç, 2013:1-4).

Dijital ekonominin vergilendirilmesi birinci eylem planı olarak dijital ekonominin tehdit oluşturup oluşturmadığı konusundadır ve dolaylı ve dolaysız vergiler için incelenmesi gereken hususları şöyle belirtmiştir (Turunç, 2013: 4).; 
i) Şirketlerin, mevcut uluslararası kurallar arasında yeterli düzeyde bağlantı kurulamaması nedeniyle, vergilendirilme yükümlülüğü altına girmeden bir başka ülke ekonomisi içerisinde dijital mevcudiyete sahip olma kapasitesi, belirlenmesi,

ii) Yeni iş modellerinden elde edilen gelirlerin karakteristik özelliklerinin

iii) İlgili kaynak kuralının uygulanması ve dijital mal ve hizmetlerin sınır ötesi dolaşımının sebep olacağı KDV ya da mal ve hizmet vergilerinin nasıl belirleneceğidir.

BEPS eylem planı, dijital ekonomide çözüm önerisi teklifini oluşturmuştur. Özellikle tüketim vergileri üzerinde durulmuştur (OECD, 2015: 86). Buna göre yerleşik ve yerleşik olmayan satıcılar arasındaki işlemlerde KDV'nin hiç ya da çok az miktarda olması ülkelerin KDV gelirlerini olumsuz etkilemektedir. Dijital ekonomide KDV'deki temel sorun i) Bazı ülkelerde, online satışlardan düşük değerli olan ithalatlar KDV'den muaftır. ii) Hizmetler ve sanal malların ticaretindeki hızlı büyümeyle birlikte, özellikle bu tür şeylerin özel kişilere satışları KDV'nin ödenmesindeki karmaşıklıktan dolayı ya düşük ya da hiç vergilendirilmez (OECD, 2015: 120). Bu durum dijital ekonomide KDV'nin tahsilatında sorun yaratmaktadır.

BEPS projesi kapsamında dijital ekonominin vergilendirilmesi için bazı öneriler geliştirilmiştir. Bunlar şöyledir; B2B (işletmeden-işletmeye) hizmetlerde hizmetin vergilendirileceği yer, varış yeri ilkesine göre belirlenir. Bu hizmetler müşterinin bulunduğu yerdeki KDV'ye tabi olur. $A B^{\prime}$ de yer alan "mini one stop shop" ${ }^{5}$ sistemine benzer bir öneri sunulmuştur. Dijital alt yapılar ile uzaktan gerçekleştirilen B2B işlemlerde, hizmetin gerçekleştirildiği yer, müşterinin yerleşik olduğu yer veya birden fazla yerde yerleşik ise, hizmetten faydalanan kuruluşun yerleşik olduğu yer kabul edilir ve tevkifat işleminde bu yer göz önünde bulundurulur (PWC, 2015: 46).

1 Ocak 2015 'den itibaren, gerçek kişiler ve işletme olmayan müşterilere verilen telekomünikasyon, yayın ve elektronik hizmetler müşterinin bulunduğu üye devlette vergilendirilir (PWC, 2015:46).

Yerleşik olmayan satıcının KDV uyumu ve kaydı için, temel bazı önlemler alınabilir. Yerleşik olmayan işletmeden-müşteriye (B2C) sanal mal ve hizmet satışı kayda dayalı tahsilat sistemiyle kolaylaştırılması temel önerileri ve işletmedenişletmeye (B2B) uluslararası sanal mal ve hizmet satışında yerleşik olmayan satıcılar için orantılılık prensibi ve kayıt temelli sistemin olması gerekir. Bu sitem için; kayıt, iade, ödemeler, kayıt tutma, faturalama, bilginin erişebilirliği, üçüncü taraf servis sağlayıcıları kullanımı gibi hususlara dikkat edilmelidir (VAT, GST, 2015: 51).

5 Mini-One-Stop-Shop (Mini Tek Durak Mağazası): Avrupa Birliğinin kurduğu bir KDV sistemidir. Buna göre, satıcılar AB üyesi ülkelerden herhangi birisinde MOSS'a kaydolabilir, üçer aylık dönemler itibariyle elektronik ortamda KDV beyanında bulunabilir. Toplanan KDV MOSS'a aktarılır ve MOSS da bunları ilgili ülkelere elektronik ortamda transfer eder. MOSS'a üye olmayan satıcılar ise üçer aylık dönemler itibariyle doğrudan ilgili ülkeye KDV beyanında bulunup ödeme yaparlar. 


\section{Türkiye'de Elektronik Ticaret Kapsamında KDV Uygulaması}

KDV'nın konusu, mükellefi, teslim ve teslim sayılan haller, hizmet ve hizmet sayılan haller, vergiyi doğuran olay Katma Değer Vergisi Kanunu'nun ilk on maddesinde düzenlenmiştir. KDV açısından elektronik ticarete baktığımızda ürün ve hizmetleri iki ayrı biçimde değerlendirebiliriz. İlk olarak; internet üzerinden sipariş edilerek teslim edilen fiziki mallar; ikincisi ise dijital ürünlerin çevrimiçi teslimi şeklinde sunulan hizmetlerdir. OECD’nin KDV ile ilgili temel ilke kararları: Vergilemenin tüketimin yapıldığı yerde yapılması, dijital ürünlerin hizmet olarak değerlendirilmesi, vergi toplama mekanizmalarının geliştirilmesinden oluşmaktadır. OECD ilkeleri açısından Türk vergi sisteminde harcama vergileri açsından vergilemede tüketim yeri ilkesi uygulanması nedeniyle sorun oluşturmamaktadır (Çetin, 2011: 65).

Mal ve hizmet ayrımı yapılırken 4503 Sayılı Kanunla KDV Kanunu'nun 6.b maddesi ile $A B$ ülkelerinin hem KDV hem de dolaylı vergiler konusunda uyum sağlamak için oluşturdukları 6 No'lu direktif doğrultusunda yapılmıştır. Elektronik ticarette genel olarak maddi nitelik taşıyan malların gayri maddi türevlerinin KDV Kanunu uygulaması açısından kabul gören hizmet olarak değerlendirilmesi gerekir. Bunun için ayrı bir tanım hükmü getirilmelidir (Yaltı, 2003: 233). KDV Kanunu'na göre bir işlemin nerede vergilendirileceği coğrafi olarak bir yere bağımlılık esasına dayandırılmıştır. Hizmetin yapıldığı veya işlemi yapan kişinin bulunduğu yer vergilemenin yapılacağı yer olacaktır.

Türk vergi sisteminde dış ticaretin vergilendirilmesi açısından KDV'de "varış ülkesi" ilkesi uygulandığından mal ve hizmetler tüketildikleri yerde vergiye tabi tutulmaktadır. Buna göre, ülkeler ihraç ettikleri mal ve hizmetlere KDV istisnası uygularken, ithal ettikleri ürünlerden KDV tahsil etmektedir. Ancak, dijital ürünlerde yabancı ülkeden ekonomik bir değeri olan herhangi bir dijital ürünün Türkiye'ye gönderilmesi durumunda, bu ürünün vergi idaresi tarafından belirlenmesi ve vergilendirilmesi oldukça zordur (Ceran, Çiçek, 2007: 302). Günümüzde bu işlemlerin tespiti için çeşitli teknolojik alt yapıya dayanan sistemler oluşturulmuştur.

Hizmetin Türkiye'de yapılması, hizmetin fiilen Türkiye'de verilmesini ifade eder. Bir hizmet, fiilen Türkiye'de verildiği takdirde, başka hiçbir ölçüte gerek kalmadan Türkiye'de yapıldığı kabul edilir. Fiilen Türkiye'de yapılan ancak yurt dışkındaki müşterilere yönelen hizmetler vergiden istisnadır (KDVK, md. 11/1(a)). Hizmetin fiziksel olarak Türkiye'de verilmediği hallerde, hizmetten Türkiye'de faydalanılması durumunda ifa yeri Türkiye sayılır. Yurt dışında verilen bir hizmetten Türkiye'de faydalanıldığı için Türkiye'de yapılmış sayıldığından, burada bir ithalat değil "Türkiye'de yapılan bir hizmet" söz konusu olur. KDV Kanunu'na göre bu ilişkide vergi mükellefi yurt dışındaki kişi veya kurumdur (Yaltı, 2003: 235).

Katma Değer Vergisi'nde esasında bulut bilişim faaliyetlerine yönelik vergileme uygulamaları da bulunmaktadır. Kanun'un 1'inci maddesinin 1'inci fıkrasının 2'inci bendi, Türkiye'de yapılan her türlü mal ve hizmet ithalatının KDV'ye tabi olduğu belirtilmektedir. Aynı zamanda 6'ncı maddenin birinci fıkrasının b bendinde, hizmetin Türkiye'de verilmesinin ya da hizmetten Türkiye'de faydalanılması işlemlerinin 
Türkiye'de yapılması anlamına geldiği belirtilmiştir (KDVK, 1984). Tüm bu hükümlere göre yurtdışında yerleşik firmalardan sunucu kiralama ve internet hizmeti ithalatı (gayri maddi hak) gibi bulut bilişim hizmet alımları KDV'ye tabi olmakta ve bu hizmetten faydalanan Türkiye'de yerleşik (mukim) kişi tarafından ödenmesi gerekmektedir (KVK ve KDVK Özelge, 2013). (Turan, 2014: 318-319).

26.04.2014 tarihli Resmi Gazete'de yayınlanan KDV Genel Uygulama Tebliği ile 01.05.2014 tarihine kadar yayınlanmış olan tüm KDV tebliğleri yürürlükten kaldırılmıştır. Bu Tebliğe göre "Yurtdışındaki firmaların, Türkiye'ye gönderecekleri mal ve hizmetler Türkiye'de tüketildiğinden, bu firmalara söz konusu mal ve hizmetler için Türkiye'de verilen danışmanlık, aracılık, gözetim, müşteri bulma, piyasa araştırması vb. hizmetler, hizmet ihracı istisnası kapsamında değerlendirilmez ve KDV'ye tabidir. Bu durumda faydalanma kriterinin tespitinde, yapılan hizmetin ithal edilen mal ile doğrudan ilişkili olması gerekir. Yabancı firmaların Türkiye'den ithal ettiği (Türkiye'nin ihraç ettiği) mallar dolayısıyla verilen hizmetler, hizmet ihracı kapsamında değerlendirilir. Türkiye'den serbest bölgelere verilen hizmetler hizmet ihracı kapsamında değerlendirilmez".

01.05.2014 tarihinde yürürlüğe giren KDV Genel Uygulama Tebliği ile ilgili bu yeni düzenleme, elektronik ticaret kapsamına giren elektronik mal ve hizmetlerin de ancak yabancı firmaların işlerinden bağımsız olma koşulu ile yapılan hizmet ihracı istisnasından faydalanmanın geçerli olacağını göstermiştir. Ayrıca serbest bölgelere verilen elektronik hizmetler de bu durumda hizmet ihracından faydalanamayacaktır.

Elektronik ticaretin taraflarının belirlenmesi açısından diğer önemli düzenleme de VUK tasarısında yer almaktadır. "Dijital İşyeri" tanımı ve dijital ticari faaliyetlerin vergileme rejimi BEPS eylem planı eylem 1 de düzenlenmiştir. Bu doğrultuda Türkiye'de VUK Tasarısı Taslağı'nda da Md. 129 “işsyeri” VUK Tasarı Md. 130 “Elektronik Ortamda İşyeri" tanımları düzenlenmiştir". Görüldüğü gibi Türk Vergi Sistemi’nde de dijital ekonominin unsurlarının netleşmesi yolunda ilerlemeler, tüm dünyayı çerçevesine alan ve kendine hızla yer eden bilişim çağında elektronik ticaret ve buna ilişkin vergi mevzuatının oluşması açısından önemli bir konu haline gelmiştir.

\footnotetext{
6 iş yeri MADDE 129- (1) İş yeri, mağaza, yazıhane, idarehane, muayenehane, imalâthane, şube, satış yeri, atölye, depo, laboratuvar, sergi ve teşhir salonu, eğitim ve kurs yerleri, ev ofis, müzayede salonu, otel, kahvehane, eğlence ve spor yerleri, tarla, bağ, bahçe, çiftlik, hayvancılık tesisleri, dalyan ve voli mahalleri, tuzla, taş ve maden ocakları, şantiyeler, yük ve yolcu taşıma araçları, vapur büfeleri, mobil araçlar, elektronik ortam veya alanlar gibi ticari, sınai, zirai veya mesleki bir faaliyetin icrasına tahsis edilen veya bu faaliyetlerde kullanılan yerdir.

Elektronik ortamda iş yeri MADDE 130- (1) Internet, ekstranet, intranet ya da benzeri bir telekomünikasyon ortam veya aracının ticari, sınai veya mesleki faaliyete tahsis edilmesi veya bu faaliyetlerde kullanılması durumunda elektronik ortamda iş yeri oluşur. (2) Maliye Bakanlığı, elektronik ortamda oluşan iş yerlerinin kapsamına ve mükellefiyetle ilgili ödevlerin yerine getirilmesine ilişkin hususları belirlemeye, elektronik ortamda oluşan işyerleri vasıtasıyla mal veya hizmet temininde ya da bunların bedelinin ödenmesinde aracılık yapan kişiler ile mal veya hizmetin alıcılarını ilgili vergilerin ödenmesinden müteselsilen sorumlu tutmaya ve uygulamaya ilişkin usul ve esasları belirlemeye yetkilidir.
} 


\section{Sonuç}

Elektronik ticarette KDV konusu, özellikle uluslararası alanda değerlendirilmesi gereken bir konudur. Ülke sınırları içerisinde takibi ve kayıt altına alınması, teknolojik alt yapının ve mevzuatın hazır olduğu ülkelerde, denetimin de daha kolay yapılmasından dolayı uluslararası takibine göre zor değildir. Elektronik ticaret; mal ve hizmetlerin sipariş edilip geleneksel yöntemlerle teslimi veya mal ve hizmetlerin tamamen elektronik ortamda tesliminden oluşur. Sanal mallar dediğimiz elektronik mal ve hizmetlerin uluslararası ticarette takip edilmesi, birçok ülkenin ve ekonomik kuruluşların dikkatini çekmiştir. Çünkü farklı ülkelerde farklı vergi oranları ve uygulamalarla müşteriler arası, işletmeler arası, işletmeden-müşteriye sanal mal ve hizmet satışında haksız rekabet sorunlarıyla karşılaşılmaktadır. 2000'li yılların en önemli konusu haline gelen elektronik ticaretin vergilendirilmesi konusunda, özellikle KDV'nin durumu OECD ülkelerinde ve $A B^{\prime}$ de ortak bir hukuk birliği oluşturulması için çeşitli önlemleri içeren direktiflerle düzenlenmeye çalışılmıştır. Günümüzde elektronik ticaret satışları 1.4 trilyon doları aşmıştır. 2018'de bu rakamın 2.356 trilyon dolara ulaşacağı tahmin edilmektedir. Dünya nüfusunun neredeyse yarısının internet kullanıcısı olduğunu düşünürsek, bu rakamın daha da artacağını söyleyebiliriz. KDV, OECD ülkelerinin hemen hemen hepsinde uygulanan bir vergi olarak, elektronik ticarette devletlere önemli bir gelir sağlayan bir vergi konumundadır. Vergi gelirleri içinde yaklaşık \%30'nu oluşturur. Böylesine önemli bir gelir kaynağı için $A B$ ve $O E C D$ düzenlemeler yapmıştır. OECD uluslararası KDV tasarımı ve işlemleri ile ilgili standartlar belirlemiştir. KDV'nin tarafsızlığı üzerine standartlar, uluslararası ticarette vergileme haklarının dağılımıyla ilgili standartlar, vergilemede tarafsızlık ve adalet prensipleri için önemli düzenlemelerdir. 2014'te yayınlanan BEPS raporunda "Dijital Ekonominin Vergi Sorunları" başlığı altında KDV konusunda uluslararası bir çerçevenin eksikliğinden bahsedilmiş ve özellikle tüketim vergileri üzerine çözüm önerileri getirilmiştir. Hizmetin vergilendirileceği yerin varış yeri olması, müşterinin bulunduğu yere göre vergilendirilmesi standardı getirilmiştir.

Türk vergi sisteminde dış ticaretin vergilendirilmesi açısından KDV'de "varış ülkesi" ilkesi uygulanmaktadır. Buna göre, ülkeler ihraç ettikleri mal ve hizmetlere KDV istisnası uygularken, ithal ettikleri ürünlerden KDV tahsil etmektedirler. Günümüzde elektronik ticaretin takibi için çeşitli teknolojik alt yapıya dayanan sistemler oluşturulmuştur. Elektronik ticarette, adil bir vergi sistemi 1998 Ottawa Konferansı'ndan bu yana tartışılmaktadır. Tarafsızlık, elektronik ticarette KDV'nin eşit ve tarafsız şekilde düzenlenmesinde en önemli prensip olmuş ve bunu sağlamaya yönelik önlemler düzenlenmiştir. 


\section{KAYNAKÇA:}

Çetin Gerger, G. (2011). "Elektronik Ticarette Tüketim Vergisi Olarak KDV'nin Etkinliği”, Ekonomi Bilimleri Dergisi, Cilt 3, No 1, ISSN: 1309-8020 (Online)

European Commission. (2014). Directorate-General Taxation And Customs Union, Indirect Taxation and Tax administration Value Added Tax, "http://ec.europa.eu/taxation_customs/resources/documents/taxation/vat/ho w_vat_works/telecom/explanatory_notes_2015_en.pdf" (28.11.2015).

Ferhatoğlu, E. (2006). "Avrupa Birliği Ortak Katma Değer Vergisi Sisteminde Elektronik Ticaret", Eskişehir Osmangazi Üniversitesi Sosyal Bilimler Dergisi, Cilt: 7, Sayı: 2, Aralık 2006, ss. 47-65.

Mclure, C. E. (2003). The Value Added Tax on Electronic Commerce in the European Union, International Tax and Public Finance, 10 (6): 753-762.

National Audit Office. (2006). HM Revenue \& Customs Vat on E-Commerce, London, www.nao.org.uk

OECD. (2015). Addressing the Tax Challenges of the Digital Economy, Action 1 - 2015 Final Report, OECD/G20 Base Erosion and Profit Shifting Project, OECD Publishing, Paris. http://dx.doi.org/10.1787/9789264241046-en

OECD. (2014). Consumption Tax Trends 2014, OECD Publishing. http://dx.doi.org/ 10.1787/ctt-2014-en

OECD. (2013). Adressing Base Erosion and Profit Shifting, OECD Publishing.

http://dx.doi.org/10.1787/9789264192744-en

OECD. (2015). INTERNATIONAL VAT/GST GUIDELINES, Paris.

OECD. (2001). Taxation and Electronic Commerce Implementing the Ottawa Taxation Framework Conditions, E-Book.

PWC. (2015). E-Ticaret Vergi Uygulamaları, https://www.okul.pwc.com.tr/images/ uploadfile/content/635863141533679504.pdf (14.01.2016).

T.C. Avrupa Birliği Bakanlığı. (2016). http://www.ab.gov.tr/index.php?p=81-, Erişim: 22.1.2016.

Turan, M. (2014). "Bulut Bilişim ve Mali Etkileri”, Bilgi Dünyası, 15(2), 296-326.

Turunç, S. (2013). Matrah Aşındırma ve Kar Aktarımı, BEPS, T.C. Maliye Bakanlığı Avrupa Birliği ve Dış ilişkiler Dairesi Başkanlığı.

TUSIAD. (2014). Dünya'da ve Türkiye'de E-Ticaret Dijital Pazarın Odak Noktası ETicaret (Yayın No: TUSiAD-T/2014-06/553) "http://e-ticaretzirvesi.org/turkiyeve-dunyada-e-ticaret/"

UN. (2005). Technology Transfer and Taxation: Key Issues, New York and Geneva.

Şenyüz, D., Yüce, M., Gerçek, A. (2015). Türk Vergi Sistemi, 12. baskı, Ekin Basım yayın Dağıtım, Bursa.

Vidyasekar, A. D. (2014). Future of B2B Online Retailing, www.frost.com.

Yaltı, B. (2003). Elektronik Ticarette Vergilendirme, Der Yayınları, İstanbul. 